\title{
Growth of the gastrointestinal tract of pigs during realimentation following a high-fibre diet*
}

\author{
S. Raj ${ }^{1}$, G. Skiba, D. Weremko and H. Fandrejewski \\ The Kielanowski Institute of Animal Physiology and Nutrition, \\ Polish Academy of Sciences \\ 05-110 Jabtonna, Poland
}

(Received 21 February 2005; revised version 9 September 2005; accepted 17 October 2005)

\begin{abstract}
The aim of this experiment was to investigate the growth of the gastrointestinal tract of pigs on which compensatory growth was imposed by previously feeding them a high-fibre diet (HF). Fortytwo pigs of $25 \mathrm{~kg}$ BW were randomly allotted to 3 treatment groups. The pigs were fed ad libitum a basal diet (B) during the whole of the experiment (control group, C), or a high-fibre diet (HF) up to 50 or $80 \mathrm{~kg} \mathrm{BW}$ (groups HF50 and HF80, respectively), followed by diet B up to $105 \mathrm{~kg} \mathrm{BW}$. Diet $\mathrm{B}$ contained (in DM, $\mathrm{g} \mathrm{kg}^{-1}$ ): crude protein, 212; crude fibre, 43; total lysine, 11.1, and metabolizable energy, 14.7 MJ. Diet HF was formulated by mixing diet B with $20 \%$ of grass meal and contained: crude protein, 191; crude fibre, 85; total lysine, 9.1, and metabolizable energy, 12.9 MJ. The animals of each group were slaughtered at 50,80 and $105 \mathrm{~kg} \mathrm{BW}$. The weights of the empty gastrointestinal tract (GIT) and other organs were recorded. The GIT and digesta weights of pigs fed the HF diet up to 50 or $80 \mathrm{~kg} \mathrm{BW}$ (restriction period) were significantly higher compared with the pigs fed diet $\mathrm{B}$, by 8.5 and $12.4 \%(\mathrm{P}<0.05)$, and by 36.3 and $67.4 \%(\mathrm{P}<0.01)$, respectively. At $105 \mathrm{~kg} \mathrm{BW}$ (after the realimentation period) the weight of the GIT, carcass weight and dressing percentage of pigs fed diets HF for a period (groups F50 and F80) were similar to pigs fed the basal diet throughout the experiment.
\end{abstract}

KEY WORDS: pig, fibre, compensatory growth, gastrointestinal tract

\footnotetext{
* Founded by The European Commission (V Framework Programme) within the international project "Sustainability in the production of pork with improved nutritional and eating quality using strategic feeding in out-door production", Contract No. QLK5-CT-2000-00162

${ }^{1}$ Corresponding author: e-mail: s.raj@ifzz.pan.pl
} 


\section{INTRODUCTION}

In outdoor pig production systems, roughages are used as a complement of daily allowances. In general, roughages are characterized by lower density of energy, amino acids and minerals as compared with concentrate feed, therefore these feeds worsen the production efficiency of pigs. On the other hand, it is well known that pigs growing below their genetic potential can show compensatory growth if adequate nutrition is reinstated (Bikker, 1994; Skiba et al., 2001). The compensatory growth phenomenon is being applied with increasing frequency to increase the benefits of outdoor rearing.

Growth of the gastrointestinal tract (GIT) of pigs undergoing compensatory growth depends on the kind and duration of restriction. Pigs restricted for feed intake have, at the end of the restriction, lower, while those restricted for protein intake, the same weight of internal organs as compared with non-restricted animals (Fandrejewski, 1994; Crister et al., 1995). If adequate feed is provided again (realimentation), however, those that have a lower visceral weight are able to compensate it to the size of control pigs due to allocation of some part of compensatory growth to the non-carcass part of the body (Stamataris at al., 1991; Skiba et al., 2001).

It is well known that increasing the dietary fibre content results in increased weight and capacity of the GIT, and a consequence of this is a decrease of the dressing percentage of pigs (Fernandez and Jørgensen, 1986; Jin et al., 1994; Jørgensen et al., 1996; Venk, 2001). There is no information, however, on the growth of the GIT in animals when a fibre-rich diet is changed to a commercial diet before slaughter.

A hypothesis of this experiment was that the weight of GIT organs of pigs fed a fibre-rich diet for a given period would be similar to controls if this feed is changed to a commercial diet several weeks before slaughter. Consequently the dressing percentage of pigs fed in this manner would be similar to animals fed an adequate diet during the whole experiment. Such a response of animals would improve performance and profitability of outdoor production systems. Thus, the aim of this experiment was to study the growth of the GIT of pigs restricted up to 50 or $80 \mathrm{~kg}$ BW by feeding them a fibre-rich diet (concentrate diet supplemented with $20 \%$ of grass meal) and afterwards realimenting them with a concentrate diet up to $105 \mathrm{~kg} \mathrm{BW}$.

\section{MATERIAL AND METHODS}

Forty-two crossbreed pigs ( $₫$ Duroc $\times q$ Large White) at $25 \mathrm{~kg}$ BW were randomly allotted to 3 treatment groups and kept up to $105 \mathrm{~kg}$ BW individually 
and fed according to the scheme presented in Table 1. The pigs of the control group were fed a basal diet (B) during the whole experiment. The other animals were fed a high-fibre diet (HF) up to 50 (group HF50) or up to $80 \mathrm{~kg} \mathrm{BW}$ (group HF80) and afterwards the basal diet (B) up to $105 \mathrm{~kg} \mathrm{BW}$. Therefore, the restriction period lasted up to 50 or $80 \mathrm{~kg} \mathrm{BW}$, whereas the realimentation period, up to $105 \mathrm{~kg} \mathrm{BW}$. The pigs were fed ad libitum during the whole experimental period. Feed intake was measured weekly as the difference between the amount of feed given and remaining, during both the restriction and realimentation periods.

TABLE 1

Experimental design

\begin{tabular}{lccc}
\hline \multirow{2}{*}{ Group } & \multicolumn{3}{c}{ Feed applied during particular growth period } \\
\cline { 2 - 4 } & $25-50 \mathrm{~kg} \mathrm{BW}$ & $50-80 \mathrm{~kg} \mathrm{BW}$ & $80-105 \mathrm{~kg} \mathrm{BW}$ \\
\hline C & $\mathrm{B}$ & $\mathrm{B}$ & $\mathrm{B}$ \\
HF50 & $\mathrm{HF}$ & $\mathrm{B}$ & $\mathrm{B}$ \\
HF80 & $\mathrm{HF}$ & $\mathrm{HF}$ & $\mathrm{B}$ \\
\hline
\end{tabular}

C - control group; HF50 and HF80 - groups of pigs fed high fibre diet up to 50 or $80 \mathrm{~kg} \mathrm{BW}$, respectively, and afterwards the basal diet - B, HF - high fibre diet

The two diets were formulated in pelleted form (4 mm diameter). The basal diet (B) was composed of, $\mathrm{g} \mathrm{kg}^{-1}$ : barley 309 , wheat 297 , triticale 90 , maize 50 , soyabean oilmeal 180 , rapeseed oilmeal 50 , crystalline amino acids and vitaminmineral premix 24 , and contained crude protein 212 , crude fibre 43 , total lysine 11.1, total methionine 3.4, and metabolizable energy $14.7 \mathrm{MJ}$. The high-fibre diet (HF) was formulated by mixing diet B with $20 \%$ of grass meal and contained, g: crude protein 191, crude fibre 85, total lysine 9.1, total methionine 2.9, and metabolizable energy $12.9 \mathrm{MJ}$

After a $16 \mathrm{~h}$ starvation period, the animals were slaughtered at $50(\mathrm{n}=12 ; 6$ per group $\mathrm{C}$ and HF50), $80(\mathrm{n}=12 ; 6$ per group $\mathrm{C}$ and HF80) and $105 \mathrm{~kg} \mathrm{BW}$ $(\mathrm{n}=18 ; 6$ per group C, HF50, and HF80). Next, their total gastrointestinal tract (GIT) was removed; the stomach, large and small intestines were separated and weighed before and after emptying. The length of the large and small intestines was also measured. The liver, kidneys and pancreas were separated and their weights recorded. The digesta content was determined as the difference between the weights of the full and emptied gastrointestinal tract. Both halves of the carcass were weighed separately, and then chilled at $4^{\circ} \mathrm{C}$ until the next day. Dressing percentage was calculated according to the formula: warm carcass weight, $\mathrm{kg}$ / $\mathrm{BW}, \mathrm{kg} \times 100$.

Feeds were analysed for dry matter (DM), crude protein (CP), ether extract (EE), ash and crude fibre (CF) content according to AOAC (1995). Gross energy was measured using an adiabatic bomb calorimeter (IKA C5000, Staufen, Germany). 
The neutral detergent fibre (NDF) and acid detergent fibre (ADF) contents were determined using a Fibertec System M by the method described by Van Soest (1973).

Statistical analysis of the results was performed by ANOVA analysis of variance using Statgraphics Plus software 7.0.

\section{RESULTS}

\section{Restriction period}

The performance of the pigs is given in Table 2. Average daily feed intake from 25 to $50 \mathrm{~kg}$ BW did not differ between treatments (1.90 and $1.94 \mathrm{~kg}$ ). Prolonged feeding of diet $\mathrm{HF}$ to pigs up to $80 \mathrm{~kg} \mathrm{BW}$ increased its intake by $5.1 \%$ during growth from 50 to $80 \mathrm{~kg} \mathrm{BW}$. In fact, pigs fed the HF diet began to eat more feed from the $6^{\text {th }}$ week of the restriction period. The growth rate of the pigs fed the HF diet, as compared with controls, was slower by $12.3 \%(\mathrm{P}<0.05)$ in the first and by $1.3 \%$ during the next restriction period.

TABLE 2

Daily feed intake (DFI) and average daily gain (ADG) of pigs during restriction period

\begin{tabular}{|c|c|c|c|c|c|c|}
\hline \multirow{3}{*}{ Parameter } & \multicolumn{6}{|c|}{ Restriction period } \\
\hline & \multicolumn{3}{|c|}{$25-50 \mathrm{~kg} \mathrm{BW}$} & \multicolumn{3}{|c|}{$50-80 \mathrm{~kg} \mathrm{BW}$} \\
\hline & $\mathrm{C}$ & HF50 & SEM & $\mathrm{C}$ & HF80 & SEM \\
\hline DFI, kg & 1.90 & 1.94 & 0.07 & $2.54^{\mathrm{a}}$ & $2.67^{b}$ & 0.09 \\
\hline ADG, $g$ & $900^{\mathrm{b}}$ & $789^{\mathrm{a}}$ & 34.2 & 934 & 921 & 32.2 \\
\hline
\end{tabular}

a,b $\mathrm{P}<0.05$

The weight of the empty GIT of HF50 and HF80 group pigs was significantly $(\mathrm{P}<0.05)$ heavier, by 8.5 and $12.4 \%$, respectively, compared with pigs of the group fed diet B (Table 3). The greatest changes were in the stomach, small and large intestine, as their weight at 50 and $80 \mathrm{~kg} \mathrm{BW}$ was heavier in comparison with the control pigs by 14.1 and $16.2 \%(\mathrm{P}<0.05), 4.6$ and $9.1 \%(\mathrm{P}>0.05)$, and 12.4 and $15.1 \%(\mathrm{P}<0.05)$, respectively.

The length of the small intestine of HF50 and HF80 pigs was insignificantly shorter, by 8.0 and $6.8 \%$, than in the C pigs at 50 and $80 \mathrm{~kg} \mathrm{BW}$, respectively. Large intestine length was not affected by treatment.

GIT tract digesta weight was found to be higher $(\mathrm{P}<0.01)$ by $36.3 \%$ at 50 $\mathrm{kg} \mathrm{BW}$ and $67.4 \%$ at $80 \mathrm{~kg} \mathrm{BW}$ in the pigs consuming the $\mathrm{HF}$ diet compared 
with group C. Liver, kidney and pancreas weights were unchanged irrespective of restriction duration.

TABLE 3

Weight and length of internal organs at the end of restriction period

\begin{tabular}{|c|c|c|c|c|c|c|c|c|}
\hline \multirow{3}{*}{ Parameter } & \multicolumn{8}{|c|}{ Body weight at the end of the restriction period, $\mathrm{kg}$} \\
\hline & \multicolumn{4}{|c|}{50} & \multicolumn{4}{|c|}{80} \\
\hline & $\mathrm{C}$ & HF50 & SEM & $\mathrm{P}$ & $\mathrm{C}$ & HF80 & SEM & $\mathrm{P}$ \\
\hline Slaughter weight, kg & 49.2 & 49.9 & 0.25 & 0.221 & 79.9 & 79.8 & 0.28 & 0.896 \\
\hline Dressing, $\%$ & $77.03^{\mathrm{A}}$ & $75.0^{\mathrm{B}}$ & 0.09 & 0.010 & $81.6^{\mathrm{A}}$ & $77.6^{\mathrm{B}}$ & 0.10 & 0.005 \\
\hline GIT empty, g & $2136^{\mathrm{a}}$ & $2318^{\mathrm{b}}$ & 46.60 & 0.028 & $2793^{\mathrm{a}}$ & $3138^{\mathrm{b}}$ & 72.62 & 0.017 \\
\hline Digesta GIT, g & $1430^{\mathrm{A}}$ & $1949^{\mathrm{B}}$ & 276 & 0.014 & $1689^{\mathrm{A}}$ & $2828^{\mathrm{B}}$ & 158 & 0.004 \\
\hline Stomach, g & $270^{\mathrm{a}}$ & $308^{b}$ & 10.92 & 0.049 & $396^{\mathrm{a}}$ & $460^{\mathrm{b}}$ & 16.51 & 0.046 \\
\hline Small intestine: weight, $g$ & 1127 & 1179 & 34.95 & 0.472 & 1346 & 1468 & 42.73 & 0.103 \\
\hline length, m & 14.18 & 13.04 & 0.38 & 0.168 & 15.70 & 14.63 & 0.48 & 0.199 \\
\hline Large intestine: weight, $g$ & $739^{a}$ & $831^{\mathrm{b}}$ & 25.01 & 0.034 & $1051^{\mathrm{a}}$ & $1210^{\mathrm{b}}$ & 22.67 & 0.001 \\
\hline length, m & 3.82 & 3.69 & 0.086 & 0.496 & 4.55 & 4.54 & 0.104 & 0.942 \\
\hline Liver, $g$ & 927 & 962 & 20.18 & 0.406 & 1250 & 1262 & 28.00 & 0.961 \\
\hline Kidneys, g & 215 & 213 & 6.58 & 0.825 & 315 & 299 & 8.21 & 0.921 \\
\hline Pancreas, $g$ & 85 & 81 & 3.51 & 0.245 & 113 & 120 & 4.16 & 0.484 \\
\hline
\end{tabular}

a,b $\mathrm{P}<0.05 ; \mathrm{A}, \mathrm{B} P<0.05$

\section{Realimentation period}

Group HF50 pigs consumed $7.0 \%$ more feed daily and grew $7 \%$ faster $(\mathrm{P}<0.05)$ than the pigs of group C, but only up to $80 \mathrm{~kg} \mathrm{BW}$ (Table 4).

TABLE 4

Daily feed intake (DFI) and average daily gain (ADG) of pigs during realimentation period

\begin{tabular}{|c|c|c|c|c|c|c|c|c|c|}
\hline \multirow{3}{*}{ Parameter } & \multicolumn{9}{|c|}{ Period of the re-alimentation } \\
\hline & \multicolumn{4}{|c|}{$50-80 \mathrm{~kg} \mathrm{BW}$} & \multicolumn{5}{|c|}{$80-105 \mathrm{~kg} \mathrm{BW}$} \\
\hline & $\mathrm{C}$ & HF50 & SEM & $\mathrm{P}$ & $\mathrm{C}$ & HF50 & HF80 & SEM & $\mathrm{P}$ \\
\hline DFI, kg & $2.54^{\mathrm{a}}$ & $2.72^{\mathrm{b}}$ & 0.09 & 0.05 & 3.08 & 3.11 & 3.10 & 0.08 & 0.879 \\
\hline ADG, $g$ & $930^{\mathrm{a}}$ & $993^{\mathrm{b}}$ & 46.51 & 0.05 & 1002 & 955 & 974 & 53.41 & 0.754 \\
\hline
\end{tabular}

The final weight of the total GIT, stomach, small and large intestines of pigs previously fed the HF diet (groups HF50 and HF80) were heavier compared with the pigs of the control group on average by $8.0,9.7,5.9$ and $9.7 \%$, respectively (Table 5), but the differences were insignificant. There was no difference in the length of the large and small intestines between treatments. The weights of the liver, 
kidneys and pancreas of HF50 and HF80 pigs did not differ significantly from the weights of these organs in pigs fed the control diet during the experimental period.

The amount of digesta in pigs of group HF50 was higher by only $4.6 \%(\mathrm{P}>0.05)$, but in pigs of group HF80, by $16.0 \%(\mathrm{P}<0.05)$ compared with the control pigs. Carcass weight and dressing percentage HF50 and HF80 pigs slaughtered at 105 $\mathrm{kg} \mathrm{BW}$ were similar to group C.

TABLE 5

Weight and length of internal organs at the end of realimentation period at $105 \mathrm{~kg} \mathrm{BW}$

\begin{tabular}{|c|c|c|c|c|c|}
\hline \multirow{2}{*}{ Parameter } & \multicolumn{3}{|c|}{ Group } & \multirow{2}{*}{ SEM } & \multirow{2}{*}{$\mathrm{P}$} \\
\hline & $\mathrm{C}$ & HF50 & HF80 & & \\
\hline Slaughter weight, kg & 104.7 & 104.4 & 105.0 & 0.90 & 0.905 \\
\hline Carcass weight, $\mathrm{kg}$ & 85.1 & 85.6 & 84.9 & 0.14 & 0.643 \\
\hline Dressing, \% & 81.3 & 82.0 & 80.9 & 0.11 & 0.765 \\
\hline GIT empty, g & 2984 & 3214 & 3230 & 51.14 & 0.078 \\
\hline Digesta, $g$ & $1897^{\mathrm{a}}$ & $1985^{\mathrm{a}}$ & $2201^{\mathrm{b}}$ & 85.28 & 0.049 \\
\hline Stomach, g & 450 & 499 & 488 & 12.91 & 0.160 \\
\hline Small intestine: weight, $g$ & 1346 & 1383 & 1468 & 32.53 & 0.192 \\
\hline length, $\mathrm{m}$ & 16.0 & 15.5 & 16.1 & 0.382 & 0.714 \\
\hline Large intestine: weight, $\mathrm{g}$ & 1188 & 1332 & 1274 & 33.84 & 0.143 \\
\hline length, m & 5.07 & 4.90 & 4.62 & 0.126 & 0.196 \\
\hline Liver, $g$ & 1250 & 1262 & 1264 & 28.00 & 0.961 \\
\hline Kidneys, $g$ & 356 & 344 & 322 & 14.11 & 0.753 \\
\hline Pancreas, $\mathrm{g}$ & 135 & 145 & 134 & 4.16 & 0.484 \\
\hline
\end{tabular}

a,b $\mathrm{P}<0.05$

\section{DISCUSSION}

Supplementation of the basal diet with $20 \%$ grass meal increased the crude fibre content, including both NDF and ADF fractions. As a consequence, the high-fibre diet was unbalanced with regard to energy and ileal apparent digestible amino acid content (NRC, 1998) and the amount of these nutrients was lower than the requirements of these animals.

Increasing the intake of the high-fibre diet during the restriction period allowed the pigs to intake a greater amount of nutrients (energy and crude protein), which caused their growth rate during the period from 50 to $80 \mathrm{~kg} \mathrm{BW}$ to be only slightly lower compared with pigs fed the basal diet during the entire experimental period. This unexpected response of pigs caused the severity of the restriction to lessen as its duration lengthened.

The results of the present experiment indicate that pigs given a high-fibre diet have a heavier GIT than those given the basal diet. It was found that the weight of 
the stomach, large and small intestines increased most. However, results of previous experiments concerning this matter are inconsistent. Rundgren (1988) reported increased stomach weight after feeding a diet containing oat husks. Leroch et al. (2003) obtained similar results when the pig diet was supplemented with $20 \%$ grass meal. However, Kass et al. (1980) showed increased weight of most parts of the digestive tract, but not of the stomach, by increased dietary levels of lucerne. It seems that the discrepancy of the results cited above resulted from the botanical origin of the fibre and its composition, as both strongly influence the mass of digestive organs (Venk, 2001; Goff et al., 2002). Another possible reason for enlargement of the stomach and small intestines of pigs fed a diet rich in fibre could be their higher secretory activity under the influence of greater fibre intake, given that a significantly higher output of saliva, gastric, pancreatic and biliary secretions was found in pigs fed a high-fibre diet than in those on a low-fibre diet in the study by Żebrowska et al. (1983). Moreover, Jørgensen et al. (1996) concluded that increased secretion of digestive fluids also associated with a higher activity of secretory organs resulting in enlargement of their mass.

In our study the weight of the large intestine increased but its length was not influenced by fibre intake. These changes signified adaptation of this digestive tract segment to digesting fibre. The results of previous studies by Kass et al. (1980) and Kuan et al. (1983) indicate that feeding pigs high-fibre diets increased the weight of the caecum. Rundgren (1988) reported markedly increased caecum weight after feeding a diet containing oat husks, but if brewers grain was the fibre source, the weight of the caecum was unchanged. This indicates that the type of fibrous component plays an important role in the growth of not only the stomach and small intestine but also of the large intestine. Jørgensen et al. (1996) found that a high-fibre content in the digesta increases peristalsis thereby reducing the transit time through the small and large intestine. These authors reported a five- to six-fold increase in the flow of digesta through the terminal ileum of pigs fed high fibre diets. Dietary fibre is not digested in endogenous processes in the small intestine, but is digested very efficiently by the microbial flora of the large intestine. Therefore, an abundance of fibre in the large intestine caused by feeding pigs a diet rich in this component considerably increases microbial activity in this segment of the GIT. It can also alter the anatomical characteristics of the large intestine and increase its weight (Jørgensen et al., 1996).

The amount of digesta in the GIT depends highly on the type and physical form of dietary fibre (Björklund and Pettersson, 1976; Whitemore et al., 2003). In our experiment, the amount of digesta in the pigs fed the diet containing grass meal was greater than in those fed the control diet. This was due to the high amount of fibre components exerting a propulsive effect on chyme, moving it from the small intestine to the hind gut where it is degraded by microflora (Derick et al., 1989). 
This process has a negative effect on nutrient digestion and absorption, as the time that chyme is present in the small intestine is shorter. On the other hand, an increased amount of digesta influences the dressing percentage of animals fed a high-fibre diet during the whole experiment (Just et al., 1981). In our experiment, the dressing percentage of pigs was not influenced by treatments, probably because the pigs were fed a high-fibre diet only for a specific period and because before slaughter all pigs were fed the same control diet.

No effect of the high-fibre diet on the weight of the liver and kidneys was found in our study. However, Kass et al. (1980) and Rundgren (1988) reported that pigs fed a high-fibre diet had a heavier liver and kidneys than those fed a lowfibre diet. This was probably an adaptation of the animals to a higher metabolic load caused by a greater demand for degradation of products from the fibrous component (Rundgren, 1988). The discrepancy between our results and cited studies is probably due to the kind of fibre component supplemented to the diets as well as the duration of feeding pigs the high-fibre diet.

Recent literature data has shown that the weight of internal organs is important from an economical point of view, as they strongly contribute to the net value of the carcass. Generally, many organs have an ability to adapt their growth when they are subjected to increased daily feed intake (Skiba et al., 2001; Lawrence and Fowler, 2002) and when the animals are fed a diet rich in fibre (Kass et al., 1980; Rundgren, 1988).

\section{CONCLUSIONS}

Our data indicate that after realimentation (to $105 \mathrm{~kg} \mathrm{BW}$ ) the weight of the gastrointestinal tract and net value of the carcass and dressing percentage of pigs fed a high-fibre diet were similar to pigs fed a concentrate diet during the whole experiment. Our results also prove that using compensatory growth in an outdoor production system offers a possibility to produce pigs with a similar weight and internal organ size and, consequently, with a similar net carcass weight, improving their performance and profitability of the outdoor production system.

\section{REFERENCES}

AOAC, 1995. Official Methods of Analysis, Association of Official Analytical Chemists. 15th Edition. Arlington, VA

Bikker P., 1994. Protein and lipid accretion in body components of growing pigs: effects of body weight and nutrient intake. PhD. Thesis, Wageningen Agricultural University, Department of Animal Nutrition, Wageningen (The Netherlands), pp. 1-200 
Björklund N.E., Pettersson A., 1976. The effect of grass meal and alfalafa meal on daily gain, thickness of backfat and of esophagogastric region in bacon pigs. Nord. Vet. Med. 28, 33-39

Critser D.J., Miller P.S., Lewis A., 1995. The effects of dietary protein concentration on compensatory growth in barrows and gilts. J. Anim. Sci. 73, 3376-3383

Derick N.A., Vervaeke I.J., Demeyer D.I., Decuypere J.A., 1989. Approach to the energetic importance of fibre digestion in pigs. I. Importance of fermentation in the overall energy supply. Anim. Feed Sci. Tech. 23, 141-167

Fandrejewski H., 1994. Effect of protein intake on chemical body composition, size of internal organs and energy retention in growing pigs. Energy Metabolism of Farm Animals. EAAP Publication No. 76, pp. 265-268

Fernandez J.A., Jørgensen J.N., 1986. Digestibility and absorption of nutrients as affected by fibre content in the diet of the pigs. Quantitative aspects. Livest. Prod. Sci. 15, 53-71

Goff G., von Milgen J., Noblet J., 2002. Influence of dietary fiber on digestive utilisation and rate of passage in growing pigs, finnishing pigs and adult sows. Anim. Sci. 74, 503-515

Jin L., Reynolds L.P., Redmer D.A., Caton J.S., Crenshaw J.D., 1994. Effects of dietary fiber on intestinal growth, cell proliferation, and morphology in growing pigs. J. Anim. Sci. 72, 2270-2278

Jørgensen H., Zhao X.Q., Eggum B.O., 1996. The influence of dietary fibre and environmental temperature on the development of the gastrointestinal tract, digestibility, degree of fermentation in the hind-gut and energy metabolism in pigs. Brit. J. Nutr. 75, 365-378

Just A., Jørgensen H., Fernandez J.A., 1981. Te digestive capacity of the caecum-colon and the value of the nitrogen absorbed from the hind gut for protein synthesis in pigs. Brit. J. Nutr. 46, 209-219

Kass M.L., Van Soest P.J., Pond W.G., Lewis B., McDowell R.E., 1980. Utilization of dietary fiber from alfalfa by growing swine. I. Apparent digestibility of diet components in specific segments of the gastrointestinal tract. J. Anim. Sci. 50, 175-191

Kuan K.K., Stanogias G., Dunkin A.C., 1983. The effect of proportion of cell-wall material from lucerne leaf meal on apparent digestibility, rate of passage and gut characteristics in pigs. Anim. Prod. 36, 201-209

Lawrence T.L.J., Fowler V.R., 2002. Compensatory growth. In: Growth of Farm Animals. CABI, pp. 229-254

Leroch R., Fuchs B., Szuba-Trznadel A., 2003. The effect of different levels and source of crude fibre of mixtures on length and volume of digestive tract of swine slaughtered on $90^{\text {th }}$ and $180^{\text {th }}$ day of life. Acta Sci. Pol. 2, 35-46

NRC, 1998. Nutrient Requirement of Swine. $10^{\text {th }}$ Edition. National Academy Press. Washington, DC

Rundgren M., 1988. Effects of dietary fibre, the halothane gene, transportation and mixing. Rapport of Swedish University of Agricultural Sciences, Uppsala, No. 172

Skiba G., Fandrejewski H., Raj St., Weremko D., 2001. The performance and body composition of growing pigs during protein or energy deficiency and subsequent realimentation. J. Anim. Feed Sci. 10, 633-647

Stamataris C., Kyriazakis L., Emmans G.C., 1991. The performance and body composition of young pigs following a period of growth retardation by food restriction. Anim. Prod. 53, 373-381

Van Soest P.J., 1973. Collaborative study of acid detergent fibre and lignin. J. Assn. Off. Chem. 56, 513-530

Whittemore C.T., Emmans G.C., Kyriazakis I., 2003. The problem of predicting food intake during the period of adaptation to new food: a model. Brit. J. Nutr. 89, 383-398

Venk C., 2001. The role of dietary fibre in the digestive physiology of the pig. Anim. Feed Sci. Tech. 90, 21-33

Żebrowska T., Low A.G., Żebrowska H., 1983. Studies on gastric digestion of protein and carbohydrate, gastric secretion and exocrine pancreatic in the growing pig. Brit. J. Nutr. 49, 401-410 


\section{STRESZCZENIE}

\section{Rozwój narządów przewodu pokarmowego w czasie wzrostu kompensacyjnego świń po okresowym żywieniu paszą z dużą zawartością włókna}

Celem badań było określenie wielkości narządów przewodu pokarmowego w czasie wzrostu kompensacyjnego świń, po okresowym żywieniu paszą z dużą zawartością włókna. Czterdzieści dwie świnie o masie ciała $25 \mathrm{~kg}$ podzielono na 3 grupy i żywiono do woli mieszanką podstawową (B) - grupa kontrolna (C), w czasie całego doświadczenia lub mieszanką o wysokiej zawartości włókna (HF) do 50 lub $80 \mathrm{~kg}$ m.c. (grupa HF50 lub HF80). Pasza B zawierała (w $1 \mathrm{~kg}^{-1}$ s.m.): białka ogólnego 212 g, włókna surowego 43 g, lizyny 11,1 g, methioniny 3,4 g oraz 14,7 MJ EM. Mieszanka HF została sporządzona poprzez wprowadzenie $20 \%$ suszu z traw do paszy podstawowej. Mieszanka ta zawierała: białka ogólnego 191 g, włókna surowego 85 g, lizyny 9,1 g, methioniny 2,9 g oraz 12,9 MJ EM.

W każdej grupie ubito świnie przy masie ciała 50, 80 i 105 kg, określono masę całego przewodu pokarmowego (GIT) i wypełniającej go treści, masę żołądka, masę i długość jelita cienkiego i grubego oraz masę wątroby, nerek i trzustki. Masa przewodu pokarmowego oraz jego treść u świń żywionych mieszanką z dużą zawartością włókna do 50 lub $80 \mathrm{~kg}$ m.c. (okres niedożywiania) była większa, odpowiednio o 8,5 i 12,4\% $(\mathrm{P}<0,05)$ oraz o 36,3 i $67,4 \%(\mathrm{P}<0,01)$ w porównaniu ze zwierzętami żywionymi dietą podstawową. Przy $105 \mathrm{~kg}$ m.c. (po okresie re-alimentacji) masa przewodu pokarmowego, tuszy oraz wydajność rzeźna świń w grupach HF50 I HF80, żywionych okresowo mieszanką włóknista, była podobna do masy i wydajności rzeźnej zwierząt w grupie C, żywionych dietą podstawową przez cały okres doświadczalny. 